\title{
ANATOMY, CHLOROPHYLL CONTENT AND PHOTOSYNTHETIC POTENTIAL IN GRAPEVINE LEAVES UNDER PLASTIC COVER ${ }^{1}$
}

\author{
GERALDO CHAVARRIA², HENRIQUE PESSOA DOS SANTOS 4 , \\ LUIS ANTÔNIO SUITA DE CASTRO ${ }^{5}$, GILMAR ARDUÍNO BETTIO MARODIN"5, \\ HOMERO BERGAMASCHI ${ }^{5}$
}

\begin{abstract}
The present study evaluated the anatomy, chlorophyll content and photosynthetic potential of grapevine leaves grown under plastic cover. The experiment was carried out in vineyards of Moscato Giallo cultivar covered and uncovered with plastic. A block design with 10 selected plants was used for each area (covered and uncovered). Twelve leaves (six of them fully exposed to solar radiation and six grown under shaded conditions) were collected from each area and were fixed and analyzed microscopically (thickness of the adaxial and abaxial epidermis and of the palisade and spongy parenchymas). Chlorophyll content and photosynthetic potential were determined in the vineyard at veraison and after harvest. Plastic covering increased the thickness of the palisade parenchyma in exposed and shaded leaves due to solar radiation restriction. However, the leaves from the covered vineyard did not have the same response to the restriction of solar radiation, as observed in the uncovered vineyard. The thickness of the adaxial and abaxial epidermis and of the spongy parenchyma did not vary due to solar radiation restriction. Chlorophyll content increased in the leaves of covered plants. The photosynthetic potential of the vines is not affected by solar radiation restriction imposed by plastic cover due to anatomical modification in leaves.
\end{abstract}

Index terms: Vitis vinifera, adaptation, grapevine, protected crop, microclimate.

\section{ANATOMIA, TEOR DE CLOROFILA E POTENCIAL FOTOSSINTÉTICO DE FOLHAS DE VIDEIRAS SOB COBERTURA PLÁSTICA}

RESUMO - O presente trabalho avaliou a anatomia, o teor de clorofila e as respostas fotossintéticas em diferentes níveis de radiação solar em folhas de videiras cultivadas sob cobertura plástica. O experimento foi realizado em vinhedo com a cultivar Moscato Giallo, com e sem cobertura plástica. A avaliação da anatomia foliar foi realizada em 10 plantas, nas áreas coberta e descoberta. No estádio fenológico de mudança de cor das bagas, em cada área, foram coletadas seis folhas expostas à radiação solar e seis sombreadas, as quais foram fixadas e micrografadas (espessuras das epidermes adaxiais e abaxiais e dos parênquimas paliçádicos e lacunosos). O teor de clorofila e o potencial fotossintético foram avaliados na mudança de cor das bagas e após a colheita. A diminuição da radiação solar pela cobertura plástica propicia um incremento da espessura do parênquima paliçádico em folhas expostas e sombreadas. As epidermes adaxiais e abaxiais e o parênquima lacunoso não variam suas espessuras em função da diminuição de radiação solar. O teor de clorofila aumenta nas folhas das plantas cultivadas sob cobertura plástica. O potencial fotossintético das videiras não é afetado pela restrição de radiação solar da cobertura plástica devido à modificação na anatomia das folhas.

Termos para indexação: Vitis vinifera, adaptação, cultivo protegido, microclima, videira.

\footnotetext{
${ }^{1}$ (Trabalho 036-12). Recebido em: 04-01-2012. Aceito para publicação em: 27-06-2012.

${ }^{2}$ Universidade de Passo Fundo, BR 285, Bairro São José, CEP: 99052-900 - Passo Fundo, Brasil. E-mail: geraldochavarria@upf.br ${ }^{3}$ Embrapa Uva e Vinho, Rua Livramento, 515, CEP: 95.700-000 - Bento Gonçalves, Brasil.E-mail: henrique@cnpuv.embrapa.br ${ }^{4}$ Embrapa Clima Temperado, Rodovia BR 392, km 78, CEP: 96.010-971 - Pelotas, Brasil. E-mail: suita@cpact.embrapa.br ${ }^{5}$ Universidade Federal do Rio Grande do Sul, Avenida Bento Gonçalves, 7712, CEP: 91.501-970 - Porto Alegre, Brasil. E-mails: marodin@ufrgs.br; homerobe@ufrgs.br
} 


\section{INTRODUCTION}

In recent years, some grape growers have used impermeable plastic films over planting rows in order to avert problems with plant health due to the excess rainfall. Some works show the microclimate changes due to mainly free water reduction in leaves, the gain in fruit quality and productivity (CHAVARRIA et al., 2007; COLOMBO et al., 2011). Regarding these aspects many studies show results improving grape (LULU et al., 2005) and wine quality (CHAVARRIA et al., 2008b), so yield (PEDRO JÚNIOR et al., 2011) emphasizes the use of plastic cover although the structural investment (COLOMBO et al., 2011).

Microclimate changes are observed in overhead plastic cover mainly increasing the maximum temperatures in $3.4^{\circ} \mathrm{C}$, decreasing wind speed in $90 \%$ and restricting photosynthetically active radiation over 30\% (CARDOSO, et al. 2008). The last one influences more the plants in their metabolic process related to gas exchange (CHAVARRIA et al., 2008a). The photosynthetic apparatus of plants under shaded conditions should be dynamic so that it can respond accordingly to restricted solar radiation (WHELLER; FEGERBERG, 2000).

Solar radiation is the determining factor of the photosynthetic process (SILVESTRINI et al., 2007). Regardless of the species, solar radiation restriction will eventually lower the photosynthetic rate, biomass, and production (HANG et al., 1984). As a compensatory mechanism, plants can change their leaf morphology and anatomy (CASTRO et al., 2005), as well as the chloroplast structure and position, chlorophyll content, and export and distribution of leaf assimilates (DWELLE, 1985). In general, plants rely on mechanisms that protect against impaired photosynthesis owing to energy reduction resulting from the restriction of incident solar radiation (RONQUIM et al., 2003).

Leaves developed under high light intensity, called "sun leaves”, are normally smaller and thicker than those developed under low light intensity "shade leaves" although such pattern may vary among species (MILANEZE-GUTIERRE et al., 2003). The thickness variation could be related to cell size mainly in parenchyma tissue (MARQUES et al., 2000).

Although there are studies pointing the importance of plastic overhead as a grape system production there is no detailed information about the photosynthesis mechanisms in this solar restriction place. The hypothesis formulated in this study is that the vine under plastic cover changes the anatomy of its leaf aiming to compensate the decreased solar radiation not compromising the yield.

The aim of the present study was to assess the effects of plastic cover on plant anatomy, chlorophyll content, and the consequent implications for the photosynthetic potential of grapevine leaves.

\section{MATERIAL AND METHODS}

The experiment was carried out in 2005-2006 in a vineyard that was being cultivated for the last seven years, located in Flores da Cunha, state of Rio Grande do Sul (2906'S, 51²0’O and altitude of 541 $\mathrm{m})$, southern Brazil, with the Moscato Giallo cultivar (Vitis vinifera L.), grafted onto a Kobber 5BB rootstock, with spacing of $3.0 \times 0.9 \mathrm{~m}$ (3.703 plants ha-1).

According to STRECK et al. (1999) classification, the vineyard is located in a Resol (EMBRAPA, 2006) and the climate in the region of the experiment is considered temperate, fundamental type (Cfb) (WREGE et al., 2011).

A Y-shaped training system, with rows oriented northeast-southwest, submitted to mixed pruning (four branches with six-eight buds and eight spurs with two buds) was used. The vineyard was divided into two parts: one with 12 rows in the planting line covered with clear woven plastic cover films sealed with low-density polyethylene, with $160 \mu \mathrm{m}$ in thickness and $2.65 \mathrm{~m}$ in width, and one with five uncovered rows, whose central lines were regarded as control plants.

A randomized block design was used for assessing leaf anatomy, with ten plants in each area (covered and uncovered). Twelve leaves were collected from the plants in each cropping system (when most bunches were at veraison - stage 85, according to the scale developed by LORENZ et al., 1995); six leaves were fully exposed to solar radiation and six were kept under shaded conditions (at bunch height). A stylet was used to remove small fragments of leaf blade tissue, measuring around 1 $\mathrm{mm}$ in width and $2 \mathrm{~mm}$ in length. The fragments were chemically stabilized using the Karnovsky's fixative (SILVEIRA, 1989). The fixative was allowed to act for $24 \mathrm{~h}$. Thereafter, a sodium cacodylate buffer of $0.2 \mathrm{M}$, pH 7.2, was used for washing, which was followed by post-fixation in buffered $1 \%$ osmium tetroxide for $2 \mathrm{~h}$.

Subsequently, the specimens were immersed in double-distilled water. Later, the fragments were dehydrated in alcohol at increasing concentrations (two baths with five minute each, with alcohol at the following concentrations: 30\%, 50\%, 70\%, 90\% and 95\%) and then submitted to three baths in p.a. 
grade acetone (10 min each). Finally, the material was soaked for 60 min in EPON AB-DMP30 resin solution and acetone using a 1:1 ratio, being constantly shaken at room temperature.

After being impregnated, the specimens were placed in EPON AB-DMP30 resin, polymerized in a temperature-controlled greenhouse at $60^{\circ} \mathrm{C}$ for five days. After polymerization, the blocks were cut in an ultramicrotome to obtain semithin sections (500 $\mathrm{nm})$. The sections were stained with $1 \%$ methylene blue and borax and assessed by light microscopy under an Olympus BX51 microscope (SILVEIRA, 1989). Each micrograph was magnified $10 \mathrm{X}$ so that the thickness of adaxial and abaxial epidermis and of palisade and spongy parenchymas of the leaves from the plants grown under plastic cover or no cover could be measured. The SPOT Insight software (Diagnostic Instruments, Inc.) was used for data processing.

The content of $a, b$ and total chlorophyll was measured at two different phenological stages (at veraison - Jan $20^{\text {th }}$, 2006, and four days after harvest - Mar $06^{\text {th }}$, 2006). For this analysis, 30 leaves were randomly collected from the covered and uncovered areas in each stage. Leaf discs measuring approximately $3 \mathrm{~cm}$ in diameter were taken from these leaves and six replicates were obtained, each with $100 \mathrm{mg}$ of leaf blade tissue. Pigment extraction analysis and determination of chlorophyll $a\left(\mathrm{mg} \mathrm{L}^{-1}\right)$ and $b\left(\mathrm{mg} \mathrm{L}^{-1}\right)$ contents were conducted according to PASSOS (1996).

Photosynthetic potential was evaluated on the same days on which leaves were sampled for chlorophyll content determination. An infrared gas analyzer (LI-6400, LI-COR) equipped with a closed chamber and a light source (LI-6400-2B) was set to give off the following photosynthetically active radiation doses every 1.5 min: 0, 90, 250, 500, 800 and $1.000 \mu \mathrm{mol} \mathrm{m}^{-2} \mathrm{~s}^{-1}$. Based on the radiation curves, the maximum $\mathrm{CO}_{2}$ assimilation rate $\left(\mathrm{A}_{\max }, \mu \mathrm{mol} \mathrm{CO} \mathrm{Cm}^{-2}\right.$ $\left.\mathrm{s}^{-1}\right)$, saturation and compensation radiations $\left({ }_{\text {sat }} \mathrm{R}\right.$ and ${ }_{\text {comp }} \mathrm{R}, \mu \mathrm{mol}$ photon $\left.\mathrm{m}^{-2} \mathrm{~s}^{-1}\right)$, quantum yield $(\varphi \mu \mathrm{mol}$ $\mathrm{CO}_{2} \mu$ mol photon ${ }^{-1}$ ) and the dark respiration rate ( ${ }_{d}$ Resp $\mu \mathrm{mol} \mathrm{CO} \mathrm{Cm}^{-2} \mathrm{~s}^{-1}$ ) were determined.

The variables related to the thickness of adaxial and abaxial epidermis and of palisade and spongy parenchymas, as well as chlorophyll content and photosynthetic potential of the leaves of covered and uncovered plants, were submitted to the analysis of variance (ANOVA), whereas the means were compared by Tukey's test ( $>0.05)$.

\section{RESULTS AND DISCUSSION}

The photosynthetically active radiation (PAR) under the cover at vegetative canopy height showed a linear reduction of $38 \%$ (angular coefficient of 0.629; $\mathrm{P}_{\beta=1}<0.0001$ ) (data not showed). Other studies conducted in Brazil with different types of covering in grapevines also demonstrated a similar decrease in PAR (LULU et al., 2005). It is known that not only the PAR radiation, but also ultraviolet radiation is reduced since the coverings have additives against UV to improve the durability of the plastic (CHAVARRIA et al., 2009).

The red to far red light ratio was reduced by $11.98 \%$ by the plastic cover (data not showed). Under shaded conditions, as is the case here, red light is more sharply reduced than the far red one (ZANINE; SANTOS, 2004) and the diffuse radiation is rich in far red light (CASTRO et al., 2005). The lower red to far red light ratio causes plants to recognize shading conditions and adapt accordingly by changing their leaf anatomy and by increasing their pigment content and photosynthetic capacity (TAIZ; ZEIGER, 2004).

The analysis of abaxial and adaxial epidermis under all light conditions did not reveal any significant differences, indicating that the changes in solar radiation produced by the plastic cover were not enough to cause anatomical changes or to affect the tissues in grapevines (Table 1). Although some studies show that variations may occur in the epidermis characteristics aiming greater efficiency in the radiation uptake (changes that make it more convex - as a lens), the major changes that occur in the leaves, when exposed to variations of radiation, is in the palisade parenchyma (MARTIN et al., 1989).

In leaves with larger exposure to solar radiation under both cropping systems, the palisade parenchyma showed a sharper relative increase than did the shaded leaves (Table 1). Note that the increase in the palisade parenchyma (22.85\%) was observed in the leaves of covered plants exposed to solar radiation compared to the same exposure in uncovered plants $(\mathrm{P}>0.01)$. The comparison of shaded leaves in both systems also revealed a relative increase (22.02\%) in the thickness of the palisade parenchyma in covered plants $(\mathrm{P}>0.05)$ (Table 1$)$. In addition to the direct effect of luminosity another aspect that can interfere in the increase in tissues and area of the leaf, as shown by CHAVARRIA et al. (2008a), is the water availability in grapevines grown under plastic cover. Considering that this factor provides a higher turgor pressure in the cells which in its turn results in higher growth (TAIZ; ZEIGER, 2004). Given this reasoning, PERI et al. (2007) observed that water deficit on summer (average $\psi \mathrm{w}=-1.3$ $\mathrm{MPa}$ ) in plants of Dactylis glomerata L. reduced the 
size of the epidermis, mesophyll and the number of abaxial epidermal cells.

In general, by comparing the relationship between palisade and spongy tissues in both positions and cropping systems, it is perceive that the leaves of covered plants (fully exposed or shaded) demonstrate a balance (close to one) between the thickness of palisade and spongy tissues. However, there is a stronger restriction on the palisade tissue than on the spongy one in leaves of uncovered plants (Table 1).

According to the data on the thickness of palisade tissue and the availability of radiation in each environment, it was possible to notice that grapevines do not increase the thickness of the parenchyma proportionally to the reduction in solar radiation, even though they follow the same trend (Table 1). This was confirmed as the reduction in radiation was larger in shaded leaves (close to the bunches), with a restriction around 55\%, and as the leaves did not respond in the same way as those which were fully exposed. Therefore, increases in thickness were similar in both types of exposure to solar radiation in covered plants (Table 1). This comparison shows that the thickness of leaves of covered plants was influenced by other factors, in addition to the decrease in shading. This is evident in Table 1 by the different response in terms of thickness, mainly of shaded leaves, but with similar availability of solar radiation.

Chlorophyll $a$ content was higher in the leaves of covered plants in both assessments, whereas that of chlorophyll $b$ was higher only in the first assessment (Table 2). Concerning the sum of these two types of chlorophyll, grapevine leaves of covered plants showed higher values at both phenological stages, with increases of $41.1 \%$ and $36.17 \%$, for the first and second assessments, respectively (Table 2). As with typical shade leaves, which show a reduction in the contents of chlorophyll $a$ and $b$ (TAIZ; ZEIGER, 2004), grapevine leaves of covered plants also have a lower chlorophyll content (Table 2). These results indicate the attempt of these plants to biochemically offset the reduction in solar radiation in relation to the external environment, as the role of chlorophyll $b$ is to optimize photosystem II under low light conditions (NAKAZONO et al., 2001).

The amount of chlorophyll per unit of leaf area is considered an indicator of the photosynthetic capacity of plants (TAIZ; ZEIGER, 2004). Nevertheless, even though chlorophyll content was significantly higher in covered plants (Table 2), the difference in photosynthetic potential between covered and uncovered plants basically did not have a significant difference (Table 3 ). This fact highlights that all the changes in leaf anatomy and pigmentation in covered plants allowed them to obtain the same photosynthetic capacity as did uncovered plants, compensating for the restriction on solar radiation. These aspects related to the compensation of the lack of radiation are important in the first stage of photosynthesis, however vine plants under plastic cover have an advantage in the biochemical pathway due to an easier stomatal opening, considering that in this protected environment the evaporative demand is lower due to the restriction of solar radiation and lower wind speed (CARDOSO et al., 2008; CHAVARRIA et al., 2009).

Another factor observed in protected cultivation experiment indicated that the grapevine under protected cultivation tend to have leaves with larger area, what is compensatory in a photosynthetic point of view (TAIZ; ZEIGER, 2004), because, since there is solar restriction, there is an increase in leaf area per plant with photosynthetic capacity (LARCHER, 2000). It is noteworthy that it is normal a shade adapted plant to have smaller leaves, however, the observed in vines in protected environment, was that the environmental conditions (radiation restriction and greater water availability) led to larger leaf area (CHAVARRIA et al., 2008a).

As to photosynthetic potential, there were differences between covered and uncovered plants only during veraison (Jan 20 ${ }^{\text {th }}$, 2006) (Table 3). On this date, it was possible to note that the exposed leaves of covered plants had a higher photosynthetic potential under stronger light intensity (500, 800 and 1.000 $\mu \mathrm{mol} \mathrm{m} \mathrm{m}^{-2} \mathrm{~s}^{-1}$. However, in the remaining assessments, whose aim was to compare the leaves of covered and uncovered plants, no significant differences were obtained between the two cropping systems. Nonetheless, it is important to underscore that the leaves of covered plants fully exposed to radiation on Mar $06^{\text {th }}, 2006$ and shaded on the same day tended to have a higher photosynthetic potential (Table 3).

The maximum photosynthetic rate $\left(\mathrm{A}_{\max }\right)$ was not influenced by plastic cover and by exposure (fully exposed and shaded) in the veraison assessment on Jan $20^{\text {th }}$, 2006. In the subsequent assessment (four days after harvest), however, fully exposed leaves of covered plants had significantly higher rates (Table 2), which could be correlated with the difference in the development of leaf senescence between the areas.

The effect of leaf senescence on photosynthesis was observed when the same leaves were assessed 34 days later, and a decrease in $\mathrm{A}_{\max }$ was detected in all situations. In the first assessment, the plants still had 
fruits, but on the second one, the leaves were older and showed a reduction in the photosynthetic process as a result of the elimination of the main drain with the harvest of fruits. Downton et al. (1987) removed the bunches from the plants of the Riesling cultivar and also perceived that they had a significant decline in the photosynthetic rate.

Saturation radiation $\left(\mathrm{R}_{\mathrm{sat}}\right)$, at both phenological stages, did not yield significant differences, except for the shaded leaves of uncovered plants, in which a reduction occurred in the second assessment (Table 2). This decrease of ${ }_{\text {sat }} R$ is a strategy used by leaves with lower light exposure to increase the absorption and use of light (CASTRO et al., 2005). Owing to the advanced stage of leaf senescence in the second assessment, it was also observed that compensation radiation $\left(\mathrm{R}_{\text {comp }}\right)$ was higher in the shaded leaves of uncovered plants whereas no differences were observed in the other plants with respect to this parameter (Table 2).

Neither plastic cover nor radiation exposure affected the quantum yield $(\varphi)$, but the fully exposed and shaded leaves of covered plants increased their dark respiration rate $\left(\right.$ Resp $\left._{d}\right)$ at veraison (Table 2). This is related to the higher metabolic activity of the leaves (LARCHER, 2000) of covered plants due to higher temperature and water supply under this cropping condition (CHAVARRIA et al., 2008a). This increase on ${ }_{d}$ Resp could be negative considering the carbon consumption, but in vines growth in plastic cover it always shows more dry mass contrasting this issue. It is due to although there is lost carbon with more ${ }_{\mathrm{d}}$ Resp is too more carbon gain related to the water availability in this environment.

According to the results of this experiment, it is possible to state that grapevines grown under the protection of plastic cover respond to solar radiation restriction and to the reduction in the red to far red light ratio by showing their adaptive capacity. This was corroborated by the increase in palisade parenchyma and chlorophyll content, which resulted in similar photosynthetic rates to those found here without possibly compromising carbon availability and the production potential of grapevines covered with plastic cover, as pointed out by CHAVARRIA et al. (2009).

Comparing the leaf anatomy, photosynthesis response results of this experiment and wine quality under grapes under plastic cover showed in others studies (CHAVARRIA et al. 2008b) is possible understand that solar radiation restriction do not compromises the maturation of grapes and wine final quality linked to the photosynthesis process (QUEIROZ-VONTAN et al., 2011). However, there are some modifications in ripening prolongation and improve of wine quality related to radiation restriction and fungal diseases reduction, respectively (GENTA et al., 2010).

TABLE 1 - Dimensions ( $\mu \mathrm{m}$ ) of grapevine (Vitis vinifera L.) leaf tissues of Moscato Giallo cultivar covered and uncovered with plastic film under different solar radiation exposures. Flores da Cunha-RS.

\begin{tabular}{lcccccc}
\hline \multicolumn{1}{c}{ Exposure } & $\begin{array}{c}\text { Adaxial } \\
\text { Epidermis }\end{array}$ & Palisade & Spongy & $\begin{array}{c}\text { Palisade/ } \\
\text { Spongy }\end{array}$ & $\begin{array}{c}\text { Abaxial } \\
\text { Epidermis }\end{array}$ & Total \\
\hline Covered and exposed & $15.3 \mathrm{~ns} *$ & $91.3 \mathrm{a}$ & $92.5 \mathrm{~ns}$ & $0.9 \mathrm{a}$ & $26.7 \mathrm{~ns}$ & $225.8 \mathrm{a}$ \\
Uncovered and exposed & $16 \mathrm{~ns}$ & $70.4 \mathrm{~b}$ & $112.8 \mathrm{~ns}$ & $0.6 \mathrm{~b}$ & $10.3 \mathrm{~ns}$ & $209.7 \mathrm{ab}$ \\
Covered and shaded & $12.9 \mathrm{~ns}$ & $63.5 \mathrm{~b}$ & $75.4 \mathrm{~ns}$ & $0.8 \mathrm{a}$ & $22.3 \mathrm{~ns}$ & $174.1 \mathrm{~b}$ \\
Uncovered and shaded & $14.3 \mathrm{~ns}$ & $49.5 \mathrm{c}$ & $98.7 \mathrm{~ns}$ & $0.5 \mathrm{~b}$ & $8.6 \mathrm{~ns}$ & $171.1 \mathrm{~b}$ \\
\hline
\end{tabular}

*Means in the columns with different letters are statistically significant according to Tukey's test ( $\mathrm{p}>0.05)$. ns - non significant

TABLE 2 - Chlorophyll content (mg L-1) in grapevine (Vitis vinifera L.) leaves of Moscato Giallo cultivar covered and uncovered with plastic film at two phenological stages (at veraison -Jan $20^{\text {th }} 2006$, and 4 days after harvest - Mar 06 ${ }^{\text {th }}$ 2006). Flores da Cunha-RS.

\begin{tabular}{cccccc}
\hline \multirow{2}{*}{ Type } & \multicolumn{2}{c}{ Covered } & & \multicolumn{2}{c}{ Uncovered } \\
\cline { 2 - 3 } \cline { 5 - 6 } \cline { 5 - 6 } & $\mathbf{0 1 . 2 0 . 0 6}$ & $\mathbf{0 3 . 0 6 . 0 6}$ & & $\mathbf{0 1 . 2 0 . 0 6}$ & $\mathbf{0 3 . 0 6 . 0 6}$ \\
$\boldsymbol{a}$ & $16.39 \mathrm{aA} *$ & $11.38 \mathrm{aB}$ & & $10.39 \mathrm{bA}$ & $8.34 \mathrm{bB}$ \\
$\boldsymbol{b}$ & $4.22 \mathrm{aA}$ & $2.82 \mathrm{aB}$ & & $1.74 \mathrm{bA}$ & $1.43 \mathrm{aA}$ \\
Total & $20.61 \mathrm{aA}$ & $14.20 \mathrm{aB}$ & & $12.14 \mathrm{bA}$ & $9.78 \mathrm{bB}$ \\
$\boldsymbol{a} / \boldsymbol{b}$ ratio & $3.87 \mathrm{bA}$ & $4.02 \mathrm{bA}$ & & $5.95 \mathrm{aA}$ & $5.81 \mathrm{aA}$ \\
\hline
\end{tabular}

*Means in the columns with small and capital letters are statistically different between treatments (covered and uncovered) and phenological stages (Jan 20 2006 and Mar 06 $\left.{ }^{\text {th }}, 2006\right)$, respectively, according to Tukey’s test ( $\left.>>0.05\right)$. 
TABLE 3 - Photosynthetic parameters in exposed and shaded leaves of grapevine (Vitis vinifera L.) of Moscato Giallo cultivar covered and uncovered with plastic film at two phenological stages (Jan $20^{\text {th }}, 2006$ - at veraison and Mar 06 ${ }^{\text {th }}, 2006-4$ days after harvest). Maximum $\mathrm{CO}_{2}$ assimilation - $\mathrm{A}_{\max }\left(\mu \mathrm{mol} \mathrm{CO} \mathrm{m}^{-2} \mathrm{~s}^{-1}\right)$, saturation and compensation radiations ${ }_{\text {sat }} \mathrm{R}$ and ${ }_{\text {comp }} \mathrm{R}$ $\left(\mu \mathrm{mol}\right.$ photon $\left.\mathrm{m}^{-2} \mathrm{~s}^{-1}\right)$; quantum yield - $\varphi\left(\mu \mathrm{mol} \mathrm{CO} \mathrm{CO}_{2} \mu \mathrm{mol}_{\text {photons }}{ }^{-1}\right)$, Dark respiration rate ${ }_{\mathrm{d}} \operatorname{Resp}\left(\mu \mathrm{mol} \mathrm{CO} \mathrm{Cm}^{-2} \mathrm{~s}^{-1}\right)$. Flores da Cunha, RS.

\begin{tabular}{ccccccc}
\hline & & \multicolumn{5}{c}{ Photosynthetic parameters } \\
\hline $\begin{array}{c}\text { Treatment } / \\
\text { Exposure }\end{array}$ & Date & $\mathbf{A}_{\text {max }}$ & ${ }_{\text {sat }} \mathbf{R}$ & ${ }_{\text {comp }} \mathbf{R}$ & $\boldsymbol{~}$ & ${ }_{\mathrm{d}}$ Resp \\
\hline Covered Exposed & $\mathbf{2 0 . 0 1}$ & $13.50 \mathrm{aA} *$ & $900 \mathrm{aA}$ & $26.92 \mathrm{aA}$ & $0.029 \mathrm{aA}$ & $-1.16 \mathrm{aA}$ \\
& $\mathbf{0 6 . 0 3}$ & $8.71 \mathrm{bA}$ & $900 \mathrm{aA}$ & $28 \mathrm{aB}$ & $0.024 \mathrm{aA}$ & $-0.43 \mathrm{bA}$ \\
& & & & & & \\
Uncovered Exposed & $\mathbf{2 0 . 0 1}$ & $11.02 \mathrm{aA}$ & $900 \mathrm{aA}$ & $31.80 \mathrm{aA}$ & $0.033 \mathrm{aA}$ & $-0.98 \mathrm{aA}$ \\
& $\mathbf{0 6 . 0 3}$ & $6.14 \mathrm{bAB}$ & $825 \mathrm{aA}$ & $43.03 \mathrm{aAB}$ & $0.024 \mathrm{aA}$ & $-1.03 \mathrm{aA}$ \\
& & & & & & \\
Covered Shaded & $\mathbf{2 0 . 0 1}$ & $11.23 \mathrm{aA}$ & $850 \mathrm{aA}$ & $32.88 \mathrm{aA}$ & $0.036 \mathrm{aA}$ & $-1.41 \mathrm{aA}$ \\
& $\mathbf{0 6 . 0 3}$ & $5.57 \mathrm{bAB}$ & $775 \mathrm{aA}$ & $34.05 \mathrm{aB}$ & $0.027 \mathrm{aA}$ & $-0.42 \mathrm{bA}$ \\
& & & & & & \\
Uncovered Shaded & $\mathbf{2 0 . 0 1}$ & $11.65 \mathrm{aA}$ & $950 \mathrm{aA}$ & $32.85 \mathrm{bA}$ & $0.030 \mathrm{aA}$ & $-1.05 \mathrm{aA}$ \\
& $\mathbf{0 6 . 0 3}$ & $3.10 \mathrm{bB}$ & $587.5 \mathrm{bA}$ & $83.52 \mathrm{aA}$ & $0.028 \mathrm{aA}$ & $-1.7 \mathrm{aA}$ \\
\hline
\end{tabular}

*Means in the columns with different small letters (between phenological stages in the same treatment) and capital letters (between cropping system and position at the same phenological stage) are statistically significant according to Tukey’s test ( $>0.05$ ).

\section{CONCLUSION}

The photosynthetic potential in the vines is not affected by solar radiation restriction imposed by plastic cover due to anatomical modification in leaves.

\section{REFERENCES}

CARDOSO, L.S. et al. Alterações micrometeorológicas em vinhedos pelo uso de coberturas de plástico. Pesquisa Agropecuária Brasileira, Brasília, v.43, n.4, p.441-447, 2008.

CASTRO, E.M. et al. Aspectos anatômicos e fisiológicos de plantas de guaco submetidas a fotoperíodos. Horticultura Brasileira, Vitória da Conquista, v.23, p.846-850, 2005.

CHAVARRIA, G. et al. Caracterização físico-química. Ciência Rural, Santa Maria, v.39, n.7, p.2.029-2.034, 2009.
CHAVARRIA, G. et al. Relações hídricas e trocas gasosas em vinhedo sob cobertura plástica. Revista Brasileira de Fruticultura, Jaboticabal, v.30, p.1.022-1.029, 2008a.

CHAVARRIA, G. et al. Incidência de doenças e necessidade de controle em cultivo protegido de videira. Revista Brasileira de Fruticultura, Jaboticabal, v.29, p.477-482, 2007.

CHAVARRIA, G. et al. Caracterização físico-química do mosto e do vinho Moscato Giallo em videiras cultivadas sob cobertura de plástico. Pesquisa Agropecuária Brasileira, Brasília, v.43, p.911-916, 2008b.

COLOMBO, L. A.; de ASSIS, A. M.; SATO, A. J.; TESSMANN, D. J.; GENTA, W.; ROBERTO, S. R. Produção fora de época da videira 'BRS Clara' sob cultivo protegido. Ciência Rural, Santa Maria, v.41, n.2, p.212-218, 2011.

DOWNTON, W.J.S.; GRANT, W.J.R; LOVEYS, B.R. Diurnal changes in the photosynthesis of field-grown grapevines. New Phytologist, Cambridge, 
v.105, p.71-80, 1987.

DWELLE, R.B. Photosynthesis and photoassimilate partitioning. In: Li, P.H. (Ed.). Potato physiology. New York: Academic Press, 1985. p. 35-58

EMBRAPA- Empresa Brasileira De Pesquisa Agropecuária. Centro Nacional de Pesquisa de Solos. Sistema brasileiro de classificação de solos. 2.ed. Rio de Janeiro, 2006. 306p.

GENTA, W. et al. Manejo de míldio no cultivo protegido de videira de mesa 'BRS Clara'. Pesquisa Agropecuária Brasileira, Brasília, v.45, p.1.3881.395, 2010.

HANG, A.N.; McCLOUD, D.E.; BOOK, K.J.; DUCAN, W.G. Shade effects on growth, partitioning and yield components of peanuts. Crop Science, Madison, v.24, p.109-115, 1984.

LARCHER, W. Ecofisiologia vegetal. São Carlos: Rima, 2000. 531p.

LORENZ, D.H. et al. Phenological growth stages of grapevine (Vitis vinifera L.) - Codes and descriptions according to the extended BBCH scale. Australian Journal of Grape and Wine Research, Adelaide, v.1, p.100-103, 1995.

LULU, J. et al. Efeito do microclima na qualidade da uva de mesa 'Romana' (A 1105) cultivada sob cobertura plástica. Revista Brasileira de Fruticultura, Jaboticabal, v.27, n.3, p.422-425. 2001.

MARQUES, A.R. et al. Variations in leaf characteristics of two species of Miconia in the Brazilian cerrado under different light intensities. Tropical Ecology, Varanasi, v.41, n.1, p.47-60, 2000.

MARTIN, G. et al. Epidermal focussing and the light microenvironment within leaves of Medicago sativa. Physiologia Plantarum, Copenhagen, v.76. n.4, p.485-492, 1989.

MILANEZE-GUTIERRE, M. A. et al.Efeitos da intensidade luminosa sobre a morfo-anatomia foliar de Bouchea fluminensis (Vell.) Mold. (Verbenaceae) e sua importância no controle de qualidade da droga vegetal. Revista Brasileira de Farmacognosia, São Paulo, v.1, n.13, p.23-33, 2003.
NAKAZONO, E.M. et al. Crescimento inicial de Euterpe edulis Mart. em diferentes regimes de luz. Revista Brasileira de Botânica, São Paulo, v.24, p.173-179, 2001.

PASSOS, L.P. Métodos analíticos e laboratoriais em fisiologia vegetal. Coronel Pacheco: EmbrapaCNPGL, 1996.

PEDRO JÚNIOR, M. J. et al. Sistema de condução em Y com e sem cobertura plástica: microclima, produção, qualidade do cacho e ocorrência de doenças fúngicas na videira 'Niagara Rosada'. Bragantia, Campinas, v.70, n.1, p.228-233, 2011.

PERI, P. L. J. M. et al. Morphological, anatomical, and physiological changes of orchardgrass leaves grown under fluctuating light regimes, Agronomy Journal, Madison, v.1, n.99, p.1.502-1.513, 2007.

QUEIROZ-VOLTAN, R.B. et al. Variações na anatomia foliar de videira Niagara em diferentes sistemas de condução. Bragantia, Campinas, v.70, n.3, p.488-493, 2011.

RONQUIM, C.C. et al. Growth and photosynthetic capacity in two woody species of Cerrado vegetation under different radiation availability. Brazilian Archives of Biology and Technology, Curitiba, v.46, n.2, p.243-252, 2003.

SILVEIRA, M. O. O preparo de amostras biológicas para microscopia de varredura. In: SOUZA, W. de (Ed.). Manual sobre técnicas básicas em microscopia eletrônica de varredura: técnicas básicas. Rio de Janeiro: Sociedade Brasileira de Microscopia Eletrônica, 1989.

SILVESTRINI, M. et al. Photosynthesis and carbon gain under contrasting light levels in seedlings of a pioneer and a climax tree from a Brazilian Semideciduous Tropical Forest. Revista Brasileira de Botânica, São Paulo, v.30, n.3, p.463-474, 2007.

STRECK, E.V. et al. Atualização da classificação taxonômica das unidades de mapeamento do levantamento de reconhecimento dos solos do Estado do Rio Grande do Sul. Porto Alegre: EMATER, 1999.

TAIZ, L.; ZEIGER, E. Fisiologia vegetal. 3.ed. Porto Alegre: Artmed, 2004. 
WHELLER, W.S.; FAGERBERG, W.R. Exposure to low levels of photosynthetically active radiation induces rapid increases in palisade cell chloroplast volume and thylakoid surface area in sunflower (Helianthus annuus L.). Protoplasma, New York, v.212, p.38-45, 2000.
WREGE, M.S.; STEIMETZ, S.; REISSER JUNIOR, C.; ALMEIDA, I.R. (Ed.). Atlas climático da região Sul do Brasil: Estados do Paraná, Santa Catarina e Rio Grande do Sul. Pelotas: Embrapa Clima Temperado; Colombo: Embrapa Florestas, 2011. 336p.

ZANINE, A.M.; SANTOS, E.D. Competição entre espécies de plantas - uma revisão. Revista da Faculdade de Zootecnia, Veterinária e Agronomia. Uruguaiana, v.11, n.1, p.103-122, 2004. 